eikon journal on semiotics

Simone do Vale

\title{
The Pussy Riot Meme: Performative storytelling in digital feminist narratives
}

Occupying the streets and expressing dissent in multitudes gathered in cyberspace networks became the logic of contemporary social movements. In addition, performance practices have been noticeably employed by activists in political narratives aimed at engaging support and mobilizing protests through social media platforms. Bearing not only the idea of performance as a disruptive tactic toward the perception of reality in everyday public spaces, but also as a political practice, Pussy Riot is addressed here as a feminist narrative meant both for the streets and digital screens. 
"Those in the road, those in the road, make way! Who stays inside? Come out! And on all lips let there be good words, holy words. Our custom for Dionysus, I will sing always for the god".

[The Bacchae, Euripides, c. 405 BC]

"Revolt in Russia - Riot! Riot! Take to the streets, live on the red, set free the rage of civil anger".

[Putin Got Scared, Pussy Riot, 2012]

Feminist grassroots activists have been increasingly experimenting with cyber culture performative genres such as memes, trolling, and stunts. It is specially the case of Russian collective Pussy Riot, whose earlier activism strategy in years 2011-2014 involved performing a masked, electro punk band in a series of video clips uploaded to YouTube.

Their tactics for voicing dissent were distinct from the ones seen in St. Petersburg and Moscow streets during the Snow Revolution - the surge of demonstrations in reaction to Putin's reelection to a third term as president ${ }^{1}$. Instead of carrying placards or shouting slogans, Pussy Riot has chosen to combine daredevil street performances and Riot Girl aesthetics into music clips. Although they can't be said to have reversed the political situation in Russia, their strategy proved to be successful in the sense that it has rendered local effects of sexism and authoritarianism globally visible. In contrast with the factual accounts behind each arrest of individual dissenters at that time ${ }^{2}$, the Pussy Riot story has swept the international media despite receiving poor local coverage, which, in addition, was ostensibly marked by anti-feminist rant (Steinholt: 2013; Sperling: 2014).

Traditionally, political participation has been understood as strictly institutionalized practices, but different forms of participation have been brought about by the emergence of virtual platforms (Shifman: 2013, p. 143). In this paper, I argue that the Pussy Riot case is illustrative of how performative, digital storytelling can enable non traditional forms of political agency for disenfranchised groups. Therefore, this paper addresses Pussy Riot's communication strategies neither as isolated performances nor videos, but as a broader digital narrative open to collective collaboration and replication - a feminist meme.

Even before the Internet, performative storytelling have played an effective role within activist networks dynamics as the memetic outbreak of restaurant sit-ins staged by the civil rights movement in 1960 has demonstrated (Polletta: 2006, p. 32; Shifman: 2013, p. 178). However, differently from the realism evoked by their modern counterparts (Reed: 2004), contemporary activist performances express a distinctly festive logic. Moreover, their carnivalesque character indicates a profound shift toward the perception of the meaning ascribed to representative democracy under globalizing conditions, particularly after the 2008 financial crisis (Bennett and Segerberg: 2012). These carnivalesque processes have come into play particularly when the embodiment of the invisible but ubiquitous powers of the global financial elite as represented by the summits of entities such as the World Trade Organization, the International Monetary Fund, or G-8 became the target of antiglobalization movements in the late 1990's
(Badiou: 2012; Tilly: 2005).

Hence, this study is supported by four major concepts: Carnival (Bakhitn, 2008); Performance (Boal, 2006), Narrative (Polletta, 2006), and Video Meme (Shifman: 2013). Combined, they provide a framework for addressing the issues entangled in Pussy Riot's digital feminist narrative. Firstly, according to Mikhail Bakhtin, in Medieval times, Carnival became an official space where seriousness was temporarily abolished. Through this aesthetics of "festive resistance", peasants could perform themselves in some sort of "second world" where discursive boundaries were suspended (2008, pp. 7- 8). Secondly, in consonance with Bakhtin's notion of the carnivalesque, performance as defined by Augusto Boal also consists of a political, spatial concept; it is a disruptive tactic through which, "Actors and audience meet on the same level of dialogue and power" (2006: p. 5). Thirdly, narratives are sequences of events causally connected in order to constitute a story (Polletta: 2006). Political narratives thus can be defined as the stories told by governments, parties, institutions, corporations, and/or citizens in order to make sense, legitimate, or confront certain distributions of power. Consequently, feminist narratives are stories aimed at confronting gendered articulations of power. Considering political narratives not merely as content, but as relations, Francesca Polletta argues that,

"More than other discursive forms, narrative demands an effort of interpretation. Following a story means more than listening: it means filling in the blanks, both between unfolding events and between events and the larger point they add up to" (2006, viii).

Adding to the understanding of narratives as discursive forms that require an active participation from the rea$\mathrm{der}^{3}$, in order to analyze the feminist narrative produced by Pussy Riot videos, I employ Limor Shifman's approach to YouTube memes as a narrative genre whose ambiguity and lack of closure triggers processes of imitation, hence inviting for collective co-creation of personalized versions. As Shifman has defined, video memes are the practice of replicating polysemic texts perceived as open to multiple interpretations and simple to imitate (2013, pp. 107- 110). Hence, a digital meme is not a unity in itself in the sense of a given original text which inspires countless repetition - a meme only exists as such as repetition, as the collectively produced mosaic of its hundreds, thousands, and even million replications. Therefore, in terms of political agency,

"Memes thus expand the range of participatory options in democracies: citizens can express their political opinions in new and accessible ways, engage in heated debates, and enjoy the process to boot. But in nondemocracies, Internet memes are not just about expanding discursive opportunities-they may represent the idea of democracy itself" (Shifman: 2013, p. 173).

Although by no means this is intended as a thorough approach to Big Data analysis, this work was also supported by the use of YouTube Data Tools (YTDT) and Gephi for the visualization of a sample of the main Pussy Riot's video network in $2012^{4}$. Since their purpose was strictly eliciting insights for the theoretical analysis, the statistics furnished by the tool were used specifically to explore other possible interesting aspects provided by the comparison between Pussy Riot, Femen, and Slutwalk's most viewed 
video's networks by the time this paper was written.

\section{Performance as politics: the two masks of Dionysus}

The 2010's have witnessed a renewed interest in feminism as reflected in the production of films like Suffragette (2015), I am Femen (2014), Free Angela Davis (2013), Pussy Riot: a punk prayer (2013), Ukraine is not a brothel (2013), and The Punk Singer ${ }^{5}$ (2013). Together with the growing number of online campaigns to raise awareness about gender inequities, the global spread of the Slut Walk movement, and the largely publicized protests performed by the transnational group Femen, Pussy Riot is one of the recent experiences held accountable for spurring Feminism back into the public debate (Mendes: 2015, p. 32).

Pussy Riot decided to criticize the authoritarian backlash in Russia through audacious public performances intended as parts of music clips to be edited, mixed, and displayed at YouTube afterwards, such as "Release the Cobblestones" (Osvobodi Bruschatku), a video clip uploaded on November 6th, 2011, where they are seen playing on the top of a scaffold in a subway station in Moscow. On July 2012, however, Pussy Riot members Nadezhda Tolokonnikova, Yekaterina Stanislavovna Samutsevich, and Maria Alyokhina were sentenced to two years in prison for engaging in "hooliganism motivated by religious hatred": they have unauthorizedly entered the altar of the Orthodox Cathedral of Christ the Savior, Moscow, and performed the protest song "Punk Prayer" (Salovaara: 2014; Sperling: 2014; Schuler: 2013; Steinholt: 2013). As a result of the combination between the ensuing online campaigns demanding their release, popular demonstrations outside Russian consulates around the world, and extensive international "hard news" media coverage, the 1:53 minutes digital version of the actual forty-second "Punk Prayer" performance at the cathedral has reached 3,040,026 views at its original channel since March, 10th, 2012.

Publicly, Pussy Riot was perceived under an identity imbued with cultural affective memories evoking female rockers, the mystery surrounding masked bands, and superhero powers, but also the insurgent masquerade multitude from the movie based in Allan Moore's graphic novel "V for Vendetta" (1982) as later "hacked" by Anonymous' own political narrative. Mainstream artists like Madonna and Paul McCartney have joined the Free Pussy Riot campaign, thus enforcing the belief that they were an actual struggling alternative band when, in fact, Pussy Riot was foreigner at the local punk rock scene. Also, in Russia, politics and punk rock have followed separate paths after the post-soviet transition in the 1990's, although punk remained acknowledged as an aesthetic aimed at resistance (Steinholt: 2013).

According to the Amnesty International database, at least 5,100 protesters were arrested in Russia during the Snow Revolution. Indeed, from March 2012 throughout 2014, the image of activists packed into a cage at Russian show trial broadcasts had become commonplace. The imprisonment of the three Pussy Riot members, though, has particularly ignited expressions of global solidarity. At Backtweets.com, a manual tracking of hashtags used by the Free Pussy Riot campaign had returned a result of 32,300 archived tweets for \#freepussyriot; 82,800 for \#pussyriot; 104,000 tweets for \#PussyRiot, and 4,140 for \#PunkPrayer. A dense cross-borders network of online support has clustered around their case, connecting a wide variety of nodes ranging from blogs, video channels at YouTube, Facebook and Wikipedia pages to mainstream papers and major human rights organizations (Salovaara: 2014, p. 473). Through the use of colorful balaclavas, the masked characters from their video clips were recreated during demonstrations, but also in flash mobs and performances specially produced for YouTube.

As an unfolding of the groundbreaking events occurred during the WTO summit in Seattle, 1999, reclaiming the public space for collective action has elicited an expanded repertoire of performance practices deeply intertwined with cyber culture genres. The Battle of Seattle was a relevant experiment of digitally networked action as expressed in the successful activist usage of web cameras, wireless devices, and an electronic sit-in, but also in the carnivalesque performances of the sea turtles parade later replicated in a wide variety of themes in political mobilizations (Reed: 2004). Lance Bennett and Alexandra Sergeberg have defined these practices as connective action - the digitally networked dynamics of interpersonal collective action as enabled by the emergence of the Web 2.0 platforms and mobile technologies (2012). Intimately associated with cyber culture repertoires, memetic performances hence play a significant role in communicating political content, which in the context of connective action becomes intrinsically personalized by the addition of each participant's own story (Shifman: 2013, p.156; Bennett and Sergeberg: 2012).

Previous studies in contentious politics argue that the symbolic repertoires developed by activists as means to claiming political transformations are vital for the further understanding of social movements (Tilly: 2005; Reed: 2004; Johnston \& Klandermans: 2004). More recent researches indicate that the combination between social media and audiovisual narratives have a definitive influence on the course of mobilizations as it was observed during the Kitchenware Revolution, the Arab Spring, Occupy Wall Street, and 15-M (Shifman: 2013; Penney and Dadas: 2013; Castells: 2012; Badiou: 2012; Bennet and Segerberg: 2012).

In addition to the ubiquity of mobile screens and wireless technologies, audiovisual content came to account for the largest share of the Internet traffic ${ }^{6}$. Unsurprisingly, social movements and grassroots activists also have been producing and distributing videos across social media platforms. They integrate narratives that provide an array of values, objectives, and representations that - once collectively legitimated - add to activist networks cohesiveness, thus playing an essential role toward the repeated occurrence of protests (Antoun \& Malini: 2013; Shifman: 2013; Bennett and Segerberg: 2012; Badiou: 2012; Castells: 2012; Polletta: 2006).

In her study of the Pussy Riot narrative, in order to distinguish contemporary activism, Inka Salovaara defines it as "affective activism", a continuous assemblage of humans, affects, performances, technological agents, and political memories that articulate both urban and virtual environments in the creation of topological, digital spaces by a given network community (2014, p.474).

However, this definition poses two problems. Firstly, protocols, algorithms, and recommendation systems play a far more active part in connective action than this understanding of digital platforms may imply (Van Dijck: 2013; 
Galloway: 2004). If we consider network communities' digital archives as places, thus we have to acknowledge that algorithms not only organize but also hierarchize these spaces. Besides being a social media platform, YouTube is also a powerful search engine and a commercial endeavor. This means that, the same video, edited in the exactly same length, may not receive the same scale of visibility at two different but equally densely connected channel networks. One has to trigger the YouTube algorithm as a cooperative actor; social media platforms are not a context where all forces - human and non-human can be said to be assembled in equal terms. In this sense, assembling processes alone do not answer for the visibility or propagation scale of any digital narrative. Like Facebook, YouTube depends on user generated content, but this content, as well as its networked connections, are manipulated by constantly shifting algorithms accordingly to these platform's own commercial objectives toward advertising revenues (Van Dijck: 2013, p.88).

Secondly, even though affect is a strong component of contemporary activist narratives, it can't be said that it accounts for the distinction between pre-digital and digital forms of contentious politics. This standpoint disregards the fact that affect as well as media contagion effects were also present in modern social movements' dynamics and that these dynamics were also shaped by the existing media. The performance originally intended for the press which led to the unfortunate death of suffragette Emily Wilding Davison during the 1913 Derby race in London speaks for itself.

From a different standpoint, Bennett and Segerberg stress that online platforms work as organizing agents in digital mediated mobilizations, thus acknowledging further cultural transformations toward new collaborative and personalized forms of participation in collective action (2012, p. 752). Indeed, among the factual accounts, the viral and memetic videos featuring performances such as flash mobs, protest songs, stunts, and masquerades have assumed a significant role in social movements' political narratives (Shifman: 2013; Castells: 2012; Day: 2011; Reed: 2004). While the employment of performative tactics by activists is not a novelty (Boal, 2006; Reed, 2005; Johnston \& Klandermans, 2004), the transnational, carnivalesque character of contemporary activist narratives is fundamentally different (Shifman: 2013; Antoun and Malini: 2013; Day: 2011; Tilly: 2005).

While the hashtag \#freepussyriot have remained on Twitter's trending topics, the epidemic spreading "balaclavamania" mobilized masked rallies opposite to Russian embassies around the world but, it has also sparked creative performances such as videos in the mimicking language of the Harlem Shake, and stunts like the topping of soviet memorials with colorful hoods ${ }^{7}$. Through a combination of performative storytelling and connective action, Pussy Riot became a meme.

In this sense, the mask, both consolidated as a symbol of multitudinary protests by the Zapatista Liberation Army and Anonymous, was Pussy Riot's trump card: although their actual stunts were too bold to be easily replicated, the mask - not only quite simple to create and fun to wear as in Carnival - evokes deeply entrenched meanings as a source of power. Rather than a means to concealing one's identity for protective measures in repressive regimes - or for impunity, as in the case of the abominable Ku-Klux-
Klan rallies - the protester mask symbolizes ideals of togetherness and equality. Moreover, it symbolizes an idea of power in togetherness. As Slavoj ŽiŽek has commented, the Pussy Riot balaclavas have expressed the notion of deindividualization (2012).

Unlike Femen's controversial enlisting norms and disregard for difference, Pussy Riot's masked performances openly embodied a playful, carnivalesque idea of multitude. Although multitude is nevertheless a class concept (the proverbial 99\%), it considers society as multiple identities entangled in assorted spheres of socially mediated value production, including linguistic productions in cyberspace. Therefore, however the multitude concept regards everyone as workers to some extent, it does not address the factory model as the epicenter of contemporary value production. Multitude, thus, is a political concept that dismantles and replaces modern abstract notions such as people and nation or even gender (Negri and Hardt: 2005).

In order to better clarify these shifts in contemporary activist narratives, it is necessary to trace a brief genealogy of the relationship between Carnival, performance, and politics. In fifth century Athens, after Cleisthenes' democratic reforms, on the early spring holiday, when the vines were pruned and the wine fermented, City Dionysia - a celebration marked by lively musical processions, dithyramb contests, dances, and ritual sacrifices shared between gods and men - harbored no exceptions for neither slaves, foreigners nor women, all of them individuals to whom it was denied a role in the political assemblies. During City Dionysia, women were allowed to leave the domestic confines and gather at the Mount Parnassus to sing and dance into an ecstatic, whirling trance, as though leaving their individuality behind. These female worshipers of Dionysus, or bacchae, were also called maenads (mainas; mad woman) after the god himself, Dionysus, the mainomenos (Rehm: 2005; Beer: 2004).

The god of fertility, but also of intoxication, Dionysus is mostly regarded by his inherent duality. Yet, Dionysus' ambivalence resides less in the altered states ascribed to alcohol ingestion than in the Greek moral abjection concerning the excesses (hybris). Represented as the forces of nature itself, both nurturing and hazardous, Dionysus is constantly shifting on the thresholds between benevolent and destructive powers. Being himself a hybrid, a son of Zeus and a mortal woman, two faced Dionysus is thus the god of pathos, comedy and tragedy. Hence, theatrical performance - as spectacle and also political strategy - has originated in his popular Athenian cults.

Since the abolition of tyranny, the most significant aspects of Athenian life grew increasingly performatic and by its turn, tragedy assumed an important part in politics. Tragedies staged the likely sorts of social conflicts and rivalries as experienced in the quest for political power and everyday struggles. Thus, because one single man could perform multiple characters with the simple aid of different linen masks, the Greek word for actor is hypokrites (ن́локрıт́ৎ) - interpreter - a far too literal meaning, distinct from the contemporary moralist sense ascribed to the word as "pretender" originated in Plato's Republic (Rehm: 2005; Beer: 2004, p. 42).

The political relevance of tragedies in Athens is frequently debated in Socratic dialogues, but specially in books IV and X of the "Republic", Socrates explains to Adeimantus and Glaucon that poetry, as mere imitation (mimesis), is 
not able to depict true representations of political issues. Hence, Socrates denounces the state pedagogical use of tragedy as a means to deceive the crowd. Indeed, tragedies became so interwoven with political life that the theater of Dionysus was erected at the foothill of the Acropolis, not far from the Pnyx where the main political assembly - the ecclesia - was held. With the exception of the agora, this impressive open building was much larger than any other public spaces in Athens. In addition, numerous actors became diplomats and engaged in political life, for their theatrical virtues in an oral culture where the spoken word was the means to power in the polis were highly valued (Arnott: 2003, p.78).

Differently from other cities described in Plato's works and traditionally interpreted as utopias, like the Atlantis, as Adi Ophir argues, the Republic lacks spatial, concrete demarcations. Ophir deduces that, otherwisely, the cities described in Timaeus, Critias, and Laws correspond to covert descriptions of the actual Athens, and the city model provided by the Republic consists of a hierarchical separation between discursive spaces. Since true discourse is episteme, no wonder mimesis was banned from the realms of politics (1991). The Socratic distinction between episteme and drama thus reflects a political hierarchy of discourse; an unequal distribution of discursive powers which performative, carnivalesque narratives can elude.

Performances are immediately related to space and territory in a political sense: by blurring the separation between stage and audience, it also suspends traditional discursive hierarchies - just as Carnival in Bakhtin's terms. In Brazil, performance became such a spatially political concept that it is also called "urban intervention" (intervenção urbana) ${ }^{8}$. Particularly since the sea turtle parades performed in Seattle, a wide variation of festive performance practices strongly connected both to pop culture and cyber culture has rapidly disseminated among activists in global scale, ranging from the Zapatista electronic sit-ins (Floodnet) to Reclaim the Streets (RTS) outdoor festive protests (Day: 2011). Recent examples are the environmentalists dressed as polar bears at the Flood Wall Street demonstrations in 2014 and the impressive hologram march projected in Madrid against the "gag law" (Ley Mordaza) in 2015.

These performances must not be dismissed as isolated events - they became paramount to contemporary social movement's narratives because, besides easily expressing a sense of victory over disproportionately powerful forces, they invite the public participation. Nonetheless, by uploading and sharing videos and photos of their performances held in concrete places, the online discursive space became the arena where contemporary activists symbolically confront their opposition - the official, serious speeches of totalitarianism, religious fundamentalism, nationalism, racism, homophobia, and sexism under the auspices of the "promotion of fear and orthodoxy by the proclamation of a 'war on terror'" (Beasley-Murray: 2007; 4).

The success of a social movement or a mobilization is hence decided at the narrative level. But differently from fundamentalist, nationalist or neo-Nazi narratives, which are based on mythical origins, cyberactivism networks such as Pussy Riot's - emerge through a totally distinct "open source" configuration, as explained by Henrique Antoun and Fábio Malini:
"If mythical narrative form defines the cohesion of a network such as Bin Laden's, it is completely inadequate for the Zapatista network and inconceivable for social war networks for NGO's, activists, anarchist groups, hacker groups, student movements, and the cyberpunk movement against the state and the corporation actors emerged in the Battle of Seattle. In the latter two cases, narrative is more similar to an experimental movie script that is written not only by the director himself but also by the actors and the crew, as the filming unfolds" (2013: 79).

In 2011, Pussy Riot emerged as a form of carnivalesque protest - an opposing discursive force to the official serious speech as produced by the Kremlin under the blessings of the disturbingly unsmiling Patriarch Kyrill. Before joining Pussy Riot, Tolokonnikova, her husband Petr Verzilov, and Samutsevich had been involved with the art activists collective Voina (War), which became widely known in June 2010 after their stunt "Dick in Captivity at the FSB": a giant phallus painted across the Liteiny Bridge, opposite to the Federal Security Service (FSB) bureau in St. Petersburg. A month later, Tolokonnikova and Verzilov uploaded the video showing themselves alternately introducing a raw chicken into her vagina in a supermarket (Sperling: 2014). Voina's work is aimed both at witnesses in public places and online video platforms, as well as Pussy Riot's would. Both collectives resorted to lowering and degradation as discursive strategies in works that only exist as such not in the duration of the performance act itself, but after it is edited, uploaded, and shared.

Lowering and degradation function as means to enunciate that what cannot be uttered under totalitarian seriousness. In sixth century Russia, on popular festivities associated with fertility, Yuletide or Shrovetide (the three days spring holiday before Ashes Wednesday), wandering medieval troupes of minstrels known as skomorokhi performed popular comic theatrical acts and songs sprinkled with naughty allusions. From the sixth century until their interdiction in 1649, they were fiercely condemned by the Orthodox Church as sinful entertainment (Swift: 2002, p. 14).

As explained by Pilkington (2014), in order to elude censorship, Russian punk scene has incorporated the Soviet tradition of "playing the fool", a local, particular ironic aesthetic with folkloric origins called "steb". As she quotes, a Russian punk rock scene member noted that, "in punk, everything needs to be ironic". The Pussy Riot narrative, however, cannot be considered ironic in such terms - they seem closer to the skomorokhi carnivalesque tradition than to soviet punk.

In the documentary "Pussy Riot: a Punk Prayer", both Tolokonnikova and Samutsevich can be seen on an allegedly Voina action ${ }^{10}$, "Kiss the Cops", involving cheek kissing female police officers on duty at Moscow subway stations, Bugs Bunny style. However, the stunt has earned them the "reproducers of patriarchal aggression" badge from disgusted Russian feminists who, in turn, did not recognize Pussy Riot as feminist activists due to what they considered rapist behavior (Sperling: 2014: 293).

Not locally acknowledged neither as punks nor feminists, Pussy Riot members were not newbies in the Russian world of radical art performance. They were inspired by Russian artists of the 1990's such as Anatolii Osmolovskii, Aleksandr Brener, and Oleg Kulik. Kulik became known for actions as "Deep into Russia" (1993), when he introduced 
his own head inside a cow's vagina. Brener has challenged Boris Yeltsin for a fight over the Lobnoye Mesto while Osmolovskii have protested against the soviet interdiction of swearing in public spaces along with his fellows from Expropriation of Art's Territory (ETI) by forming the word "dick" (khui) with their own bodies along the Red Square (Sperling: 2014, p. 300).

Like the strategies envisioned by the Situationists, these practices hark back to the modern avant-garde of the 1920 's, also marked by intense interest in tragedy masks, mostly in the sense of the depersonalization of actors (Sheppard: 2001, p. 121). Dadaism, Surrealism, and Action Painting experiments have elicited happenings such as Allan Karpov's. But being performance an elusive art, artists have been filming their work for decades so to perpetuate it. However, political art performances, as also a form of video art, derives from a cultural activism tradition particularly developed in the 1970's during the authoritarian regime in Brazil as Augusto Boal's Theater of the Oppressed, whose performance tactics were meant for political direct actions involving,

"...the theatricalisation of protest demonstrations, peasants' marches, secular processions, parades, meetings of workers or other organized groups, street commissions, etc., using all available theatrical elements, such as masks, songs, dances, choreography, etc." (Boal: 2006, p. 5).

Therefore, through the employment of balaclavas, as in Boal description of the Invisible Theatre, Pussy Riot became a performative narrative where, "There is no antagonistic relationship between the auditorium and stage, rather the two are superposed" (2006, p. 5).

As Bakhtin (2008) explained, the ancient world of the Saturnalia - the Roman festival in honor of Bacchus - made no distinctions between the serious and comic aspects of its deities; both Dionysian faces were held as "equally sacred". Throughout time, Carnival has reinvented itself as in the Russian narodnye gulian' ia and its balagany theaters, happenings, Invisible Theater, video art, flash mobs, and video memes. Still, as argued by Bakhtin, laughter, however lowering or degrading, can represent a force whose essence lays in the togetherness of bodies (2008, pp. 7- 8). As echoed in many Brazilian sambas, when Carnival is over it seems that everything falls back into place, like the Athenian bacchae returning to the restrains of the household after experiencing ekstasis or the ensuing political apathy in Russia after the Snow Revolution. However powerful Carnival may be as aesthetics, most aspects of official seriousness remain unchanged, as in the case of women oppression after a Slut Walk in a particular context, for instance, because both seriousness and laughter are forces that exist in tension. Perhaps it is the case of abandoning the modern notion of "revolution" as a process of immediate results and simply looking away from the macro political context to realize the transformation experienced at the micro-political level of the participating multitude itself.

On February 21st 2012 - the last day of Carnival and two weeks before national elections, Tolokonnikova, Alyokhina, and Samutsevich staged "Punk Prayer" at the pulpit of Christ the Savior. Generally interpreted as an act of blasphemy, in fact Pussy Riot's political tragedy has disrupted the flow of serious discourse as they offered themselves in sacrifice through the profanation of that sacred space. As Giorgio Agamben explains, the Latin word profanare has an ambiguous meaning. In order to profanate, that is, to return something from the sphere of the sacred back into secular use, one must sacrifice. The same applies in the opposite direction - sacrifice is also the means to consecrate something and thus alienate it from the use of men. The non apparent meaning of such zone of indistinction is that religion "is not what unites men and god, but rather what ensures they remain distinct". The church itself employs theatrical performances ritually, and one of its most important functions is to covert the fact that the sacrificed god retains a profane residual part (2007, p.60). By profanating the Orthodox altar, where women are not allowed as speakers, Pussy Riot has thus exposed the swindle. Perhaps, their contagious presence as sacrifice was more blasphemous than the lyrics of the song which, indeed, is offensive only toward Putin (Steinholt: 2012).

Considering not only their performances, but also the materiality of their desperately low-fi recordings and visceral lyrics; their choice to de-individualize in order to embrace otherwisely inclusive, collective anonymity, there is a heavily tragic component to the Pussy Riot narrative. Fundamentally, punk is about dissent. However, punk laughter - or irony - can also be a sad one, for it is marked by the acknowledgment of one's tragic condition either as an outsider or rogue in one's own cultural community.

Right from their first actions, the Muscovite "bacchae" and although they could not possibly control the unfolding of their narrative - were aware about the treatment reserved for dissenters under the rule of Putin and the ever increasing political influence of the Orthodox Church. In fact, Pussy Riot has performed at two distinct places ascribed with entrenched religious connotations, but "Punk Prayer" had eclipsed their enactment atop the Lobnoye Mesto on January 20th 2012, when they performed the angry verses of "Putin got scared", also translated as "Putin peed in his pants". Literally, Lobnoye Mesto means "place of skulls" as translated from the Aramaic word Golgotha (cavalry). Besides, Lobnoye Mesto, a 16th century, white stone dais close to St Basil's Cathedral, in the Red Square, is also a monument said to have been used by Ivan, the Terrible, for a public speech during his campaign to unite the Russian territory.

The strikingly powerful image of the eight women anonymously clad in colorful balaclavas, wielding guitars, clenched, raised fists, igniting purple smoke canisters, the Kremlin golden domes towering over them in the background, has became iconic overnight. Deliberately or not, they have decided to take a stand on a symbolic execution spot marked by the authoritarian state "territorial pissing". If the pop music industry, the corporate media, and audiences alike have reveled in the Apollonian aspects of punk, it is Dionysus, the mad god of tragedy and noise, which also bears the power both to please and destroy (Steiholt : 2013), who has always been its most likely patron. 


\section{Conclusion}

After the Berlin Wall fell apart in 1989 and Russia wheeled toward the path to democracy - and hence globalization and its perverse effects, such as gentrification and housing issues - it is understandable why Russia has rapidly followed into the occupying "bandwagon" under the pressures of inequalities.

In Russia, political dissent assumed new contours, mirroring itself in the now long online disseminated array of visibility strategies employed by political activists since the protests following the shutting down of the WTO's summit in Seattle and the upheavals of the Arab Spring in 2010. Over the course of unpopular economic reforms after the Soviet Union breakdown, the privatization of state companies has sparked a wave of grassroots outbreaks in addition to the dissolution of parliament by Yelstin in 1999, before he handed the presidency over to former KGB hardliner Vladimir Putin. Specially on the wake of the Second Chechen War and, later, in 2004, of the Ukrainian Orange Revolution consequences, as the discourse on terrorism entered a new path, the Russian Federation further strengthened its grip on power to stiffen dissent.

In its most assorted aspects, the Carnivalesque in the occupying phenomena is deeply entangled with the epidemic languages developed in digital environments, the rise of neoliberalism, and the disturbing sense of dispossession borne out of the increasing power held by transnational corporations over virtually every aspects of life. However, experiences such as Pussy Riot can indicate powerful means to resist them.

In 2013 and 2014, respectively, Pussy Riot reemerged in two complete new video clips, this time uploaded to the Pussy Riot Video channel - "Like a Red Prison" (Как в красной тюрьме) and "Putin will teach you how to love" (Путин научит тебя любить Родину). The third performance staged during the Sochi Olympics, though, went completely sour: after spending 21 months in prison, Alekhina and Tolokonnikova were publicly whipped by the Cossack militia and the scene circulated globally via mainstream media. Differently from the powerful stance Pussy Riot members have developed in their video clips and even during their trial, the incident reminded the problematic narrative elaborated by Femen's performances, which almost invariably end in police repression. However Femen "sextremists" have constructed an Olympian image for themselves in their own web sites, photos, and videos, their protests frequently generate more images of subjugated women than otherwise.

In order to further assess Pussy Riot as a digital feminist narrative in comparison to Femen and Slutwalk, I have mapped three different networks samples at YouTube using YTDT. It is necessary to note that, due to their constantly shifting dynamics, YouTube networks are very complex, instable objects: statistics may change at any time a new video is uploaded or an old one is rediscovered, not to mention variations in the algorithm parameters. Gephi was used to produce directed graphs of each video network sample in order to identify patterns or qualities not openly displayed at the YouTube platform.

At the time when this paper was written, Pussy Riot most viewed video was Punk Prayer uploaded by user GCasuaAczKY. Using Slut Walk as a term query, the most viewed video related to the movement was a controver- sial podcast called A Dose of Buckley loaded with antifeminist remarks about the first Slut Walk held in Toronto, 2011, and uploaded by user ktRTYNsLtGM. By its turn, Femen most viewed video was "Femen activists beaten up in Paris" uploaded by global news channel RT - formerly known as Russia Today and YouTube user vqUbPAmFPKG. These three networks varied immensely in dimension and related content. Even though GCasuaAczKY was an individual user, its average out degree, that is, its influence as source, was much higher than vqUbPAmFPKG and ktRTYNsLtGM, which featured in the smaller network observed - only 50 channels, less than half the size of the other two. Pussy Riot was the only group which has actually produced the most viewed video related to them. Although Slutwalk participants from around the globe also capture the marches on video and upload them to YouTube, the data has shown the movement is in serious disadvantage in the competition with other non participant actors' accounts. Finally, this brief exploration has confirmed what was already clear: Femen performs for the media and this is reflected on the videos almost exclusively produced by mainstream media channels.

In the digital environment, producers hold no control over their works as consumers increasingly become producers as well. However, if we ask what contemporary feminist activism may accomplish through digital narratives, the overview of these three networks has shown that autonomy - and thus surely not control or authorship - is an important asset for performative, digital narratives, especially for disenfranchised groups.

From the perspective of the videos at the YouTube platform, the unfolding and even the interruptions of the story seem to have been relevant in the Pussy Riot case. Differently from Femen and Slutwalk, whose stories apparently are not perceived as dynamic or open to collective participation, the Pussy Riot's narrative has changed a long way. As an actual film script, it varied greatly since the imprisonment of the collective's members, and its characters have endured visible transformations - Alekhina and Tolokonnikova are no longer using masks and have been widely acknowledged as feminists and freedom of speech advocates not only in the mainstream media, but also in academic circles.

Both of them had then started cooperating with international activists and released three new video clips: "I Can't Breathe", a song about Eric Garner's murder in Staten Island, New York; "Refugees", filmed at Banksy's Dismaland on September 25th, 2015; and "Chaika", a song against political corruption in Russia. The latter was filmed at an abandoned prison in Moscow and has achieved 1.558.351 views in four days since it was uploaded on February, 3rd, 2016. Even unmasked, the Pussy Riot narrative remains as open as possible to difference and singularity - "anyone can be Pussy Riot". So, if is there any moral for their story, it could be something very close to what Foucault has so beautifully taught in "For a non-fascist life", his preface to Deleuze and Guattari's Anti-Oedipos, "Do not think that one has to be sad in order to be militant, even though the thing one is fighting is abominable". 


\section{Endnotes}

${ }^{1}$ Amnesty International. "Freedom under threat in Russia". 2013. Web. 13 Nov. 2014. http://www.amnestyusa.org/russia/

${ }^{2}$ With the exception of former oil tycoon Mikhail Khodorkovsky.

${ }^{3}$ C.f. Foucault, M. (1998) What is an author? In: Faubion, J.D. (Ed). Aesthetics, Method, and Epistemology. . New York: New York Press, pp.205-222.

4 Гараджа Матвеева (GCasuaAczKY) 10 Feb. 2012. Web. <https://www.youtube.com/channel/UCit9k1QzOb_Bj3yB4VhkYFw>.

${ }^{5}$ A documentary about co-founder of the Riot Grrrl movement Kathleen Hanna.

${ }^{6}$ CISCO Visual Network Index (2014). Web. May, 2015 <http:// www.cisco.com/c/en/us/solutions/collateral/serviceprovider/ipngn-ip-next-generation-network/white_paper_c11-481360.html

7 Alex Bivol, Support for Pussy Riot in Sofia, The Sofia Globe, August 17, 2012. http://sofiaglobe.com/2012/08/17/support-forpussy-riot-in-sofia/

${ }^{8}$ C.f.: Melo, Carla Beatriz. Squatting Dystopia: Performative Invasions of Real and Imagined Spaces in Contemporary Brazil. Dissertation, University of California, adviser: Sue-Ellen Case, 2007, 261 pages; 3299533.

9 Mike Lerner and Maxim Pozdorovkin (dir.). England/Russia. 90 min. HBO, 2013.

${ }^{10}$ Blouin Artinfo. Voina Calls for Moscow Biennale Boycott Over Cop-Kissing Video. 21 Sep. 2011. Web. 20 Sep. 2014.

11 <http://blogs.artinfo.com/artintheair/2011/09/21/voina-call-formoscow-biennale-boycott-following-misattributed-cop-kissing-vid$\mathrm{eo} />$ 


\section{References}

AGAMBEN, G. (2007) Profanações. Trans Selvino J. Assmann. São Paulo: Boitempo.

ANTOUN, H. and Malini, F. (2013) A Internet e a rua: Ciberativismo e mobilização nas redes sociais. Porto Alegre: Sulina.

ARNOTT, P. D. (2003). Public and Performance in the Greek Theatre. London: Routledge.

BADIOU, A. (2012). The Rebirth of History: Times of Riots and Uprisings. London: Verso.

BAKHTIN, M. (2008). Rabelais and His World. Trans. Hélène Iswolsky. Bloomington: Indiana University Press.

BEASLEY-MURRAY, T. (2007) Mikhail Bakhtin and Walter Benjamin Experience and Form. New York: Palgrave Macmillan.

BEER, J. (2004). Sophocles and the Tragedy of Athenian Democracy. Westport, Connecticut: Praeger.

BENNET, W. L. and Segerberg, A. (2012). The logic of connective action. Information, Communication \& Society, 15:5, p739-768.

BOAL, A. (2006). The Aesthetics of the Oppressed. Trans. Adrian Jackson. London: Routledge.

CASTELLS, M. (2012). Networks of Outrage and Hope: Social Movements in the Internet Age. Cambridge: Polity Press.

DAY, A. (2011). Satire and dissent: interventions in contemporary political debate. Bloomington: Indiana University Press.

GALLOWAY, A. (2004). Protocol: how control exists after decentralization. Cambridge: MITpress.

JOHNSTON, H. and Klandermans, B. (eds.) (2004). Culture and Social Movements. Minneapolis: University of. Minnesota Press.

HARDT, M. and Negri, A. (2004). Multitude: War and Democracy in the Age of Empire. New York: Penguim Press.

MENDES, K. (2015). SlutWalk: Feminism, Activism and Media. London: Palgrave Macmillan.

PENNEY, J. and Dadas, C. (2013). (Re)Tweeting in the service of protest: Digital composition and circulation in the Occupy Wall Street movement. New Media \& Society. Vol. 16, no 1, pp. 74-90.

PILKINGTON, H. (2014). Punk - but not as we know it: rethinking Punk from a post-socialist perspective. In: Gololobov, I.; Pilkington, H. and Steinholt, Y. B. (eds). Punk in Russia: Cultural mutation from the "useless" to the "moronic. Oxon: Routledge.

POLLETTA, F. (2006). It Was Like a Fever: storytelling in protest and politics. Chicago: University of Chicago Press.

OPHIR, A. (1991). Plato's invisible cities: Discourse and Power in the Republic. London: Routledge.
REED, T. V. (2005). The art of protest: Culture and Activism from the Civil Rights Movement to the streets of Seattle. Minneapolis: University of Minnesota Press.

REHM, R. (2005). Greek tragic theatre. London: Routledge.

SALOVAARA, I. (2014). Spaces of Emotions: Technology, Media and Affective Activism. In: Miller, Toby (Ed.) The Routledge Companion to Global Popular Culture. London: Routledge, pp. 471- 480.

SCHULER, C. (2013). Reinventing the Show Trial: Putin and Pussy Riot. The Drama Review, Volume 57, Number 1, Spring (T 217).

SHEPPARD, A.W. (2001). Revealing Masks. Berkeley: University of California Press.

SHIFMAN, L. (2013). Memes in Digital Culture. Cambridge: MIT Press.

SPERLING, V. (2014). Sex, Politics, and Putin: Gender, Activism, and Political Legitimacy in Russia. Oxford: Oxford University Press.

STEINHOLT, Y. (2013). "Roars of Discontent: Noise and Disaffection in Two Cases of Russian Punk". Goddard, M.; Halligan, B. and Spelman, N. (eds). Resonances: Noise and Contemporary Music. London: Bloomsbury Academic, $121-133$.

(2012) Kitten Heresy: Lost Contexts of Pussy Riot's Punk Prayer. Popular Music and Society. Vol. 00, No. 0, pp. 1-6.

SWIFT, E. A. (2002). Popular Theater and Society in Tsarist Russia. Berkeley: University of California Press.

TILLY, C. (2005). Regimes and repertoires. Cambridge: Cambridge University Press.

VAN DIJCK, J. (2013). The Culture of Connectivity: A Critical History of Social Media. Oxford: Oxford University Press.

ŽIŽEK, S. (2012). The True Blasphemy. Dangerous Minds, Aug. 10, 2012. Web. Aug. 10 
eikon / Simone do Vale 